\title{
TEISUMAS KAIP SVARBIAUSIAS SVEIKATOS SISTEMOS FINANSAVIMO PRINCIPAS
}

\author{
Dainora Bielskytè \\ Klaipèdos miesto visuomenès sveikatos biuras \\ Taikos pr. 76, LT-9320 Klaipèda, Lietuva \\ Telefonas (+370 46) 234067 \\ Elektroninis paštas dainora@sveikatosbiuras.lt \\ Danguolè Jankauskienė \\ Mykolo Romerio universiteto Politikos ir vadybos fakulteto \\ Politikos mokslų institutas \\ Valakupių g. 5, LT-10101 Vilnius, Lietuva \\ Telefonas (+ 370 5) 2714635 \\ Elektroninis paštasdjank@mruni.eu
}

Straipsnis parengtas pagal mokslinio tyrimo, finansuojamo Europos socialinio fondo léšomis pagal visuotinès dotacijos priemonę, medžiagą (projektas „E-sveikatos plètros integruotos transformacijos: suinteresuotųjų pusių tinklo perspektyva“,

projekto kodas VP1-3.1-ŠMM-07-K-02-029)

Pateikta 2013 m. liepos 2 d., parengta spausdinti 2013 m. rugsejjo $21 \mathrm{~d}$.

$$
\text { doi:10.13165/SPV-13-1-5-04 }
$$

\section{Santrauka}

Straipsnyje teoriniu aspektu tiriamas teisumo principo reikalingumas - pateikiama teisumo principo samprata, jo vaidmuo sveikatos priežiūros ir finansavimo sistemoje, išnagrinèti Lietuvos teises aktai, reglamentuojantys teisumo principo sampratą, bei priemonès, užtikrinančios jo igyvendinimą.

Išvados ir rekomendacijos. Teisumo principo sampratos interpretaciju yra įvairiu, jos priklauso nuo mokslo srities atstovo, kuris ja interpretuoja. Lietuvos Respublikos teisés aktuose sveikatos priežiūros teisumo savvoka yra apibüdinta siaura prasme - ja siūloma reglamentuoti per sveikatos priežiūros prieinamumą, finansavimą, išlaidas, kokybę, paslaugų naudojimą. Teisumo principo užtikrinimas finansuojant Lietuvos sveikatos sistema Lietuvos Respublikos teisès aktuose nèra apibrèžtas, tačiau yra reglamentuotos priemonès, todèl siüloma reglamentuoti sveikatos priežiūros finansavimo teisumo ir sveikatos priežiūros visuomeninio finansavimo teisumo squokas.

Reikšminiai žodžiai: sveikatos sistemos finansavimas, teisumo principas, teisumo principas finansuojant sveikatos sistemą. 


\section{İvadas}

Aktualumas. Sveikata yra apibūdinama kaip didžiausia visuomenès socialinė ir ekonominè vertybè, ją galima įvardinti kaip ypatingą prekę, kuri yra gaunama ir per sveikatos priežiūros paslaugų teikimą. Taip pat sveikata yra viena iš svarbiausių žmogaus socialinių teisių. Kiekvienoje šalyje sveikatos apsaugos sistema yra skirtinga, ji priklauso nuo konkrečios valstybès santvarkos bei vyraujančių politinių ideologijų. Žmonès tikisi, kad esant sveikatos negalavimams jiems bus suteiktos svarbios medicinos paslaugos be jokio diskriminavimo nesvarbu, ar jis vargšas, ar turtuolis.

Pasaulio sveikatos organizacijos Liublianos chartijos pagrindiniai principai - sveikatos priežiūros sistema turi vadovautis teisumo, žmogiškojo orumo, solidarumo, profesinès etikos vertybėmis, turèti aiškius tikslus, būti orientuota ị kokybę ir pirminę sveikatos priežiūrą bei pagrịsta protingu finansavimu ${ }^{1}$. Europos sveikatos asamblejos PSO regioninio komiteto 61-oje sesijoje patvirtintas „Sveikata 2020“ dokumentas atkreipia dèmesį ị esminę vertybiu sistemą, kuria turètų būti grindžiamas kiekvienos Europos šalies sveikatos sistemos funkcionavimas, t. y.: visuotinę aprèptị, teisumą sveikatos santykiuose, sveikatinimo ir sveikatos priežiūros prieinamumą, solidarumą ịgyvendinant priemones, sistemos tvarumą, visuomenès dalyvavimą priimant sprendimus, orumą visuose sveikatinimo ir sveikatos priežiūros etapuose, diskriminavimo panaikinimą, skaidrumą priimant ir ịgyvendinant sprendimus, atskaitomybę ${ }^{2}$.

Lietuvos nacionalinès sveikatos tarybos sveikatos reformos rezoliucijoje yra nurodoma, kad teisingumą turi garantuoti sveikatos priežiūros institucijos, užtikrinant kiekvienam žmogui vienodomis galimybėmis tenkinti savo sveikatos poreikius ${ }^{3}$. Lietuvos Respublikos Konstitucijos 53 straipsnio 1 dalies nuostatos ịtvirtina valstybès rūpestị žmonių sveikata ir jos priežiūra: „Valstybė rūpinasi žmonių sveikata ir laiduoja medicinos pagalbą bei paslaugas žmogui susirgus. ${ }^{.4}$

Śtai Europos Sąjungos raidos strategijoje „Europa 2020“ pabrèžiamas visų šalių narių siekis ir ịsipareigojimai užtikrinti, kad Europoje būtų daugiau teisingumo ir mažiau atskirties. Europos Komisijos narys László Andoras pasakè: „Nauja ateinančio dešimtmečio Europos Sąjungos strategija „Europa 2020“, kurios vienas iš tikslų iki 2020 m. išvaduoti iš skurdo bent $20 \mathrm{mln}$. Europos gyventojų, aiškiai rodo nuoširdų visų šalių ịsipareigojimą siekti matomų rezultatų, kad Europoje būtų daugiau teisingumo ir mažiau atskirties. “5

Sveikatos politikos tikslu igyvendinimo pagrindas yra sveikatos sistemos finansai. Finansavimas yra viena svarbiausių sveikatos sistemos funkcijų. Teisumo principo užtikrinimas finansuojant sveikatos sistemą yra sudėtingas procesas, reikalaujantis itin stiprios politinès valios. Mokslininkai sutaria, kad šis principas turi būti užtikrinamas taip, kad finansuojant sveikatos priežiūrą būtų atsižvelgiama ị žmonių gebèjimą mokèti (mokumą). Joseph’as

1996 m. birželio 18 d. Liublianos chartija dèl sveikatos apsaugos reformų Europoje [interaktyvus]. [žiūrèta 2012-02-23]. <http://sec.lt/pages/spr/Alf_mok/Priedai/Chatija.html> .

2 Lietuvos sveikatos programa 2020 [interaktyvus]. [žiūrèta 2012-02-18]. <http://www.sveikatosprojektai. org/node/41>.

3 Lietuvos sveikatos reforma: dabartis ir ateitis. Nacionalinès sveikatos tarybos posèdžio rezoliucija. Sveikatos drauda. 2000, 12 (43): 3-4.

4 Lietuvos Respublikos Konstitucija, priimta Lietuvos Respublikos piliečių 1992 m. spalio 25 d. referendume. Valstybès žinios. 1992, Nr. 33-1014.

5 Europos Komisija. Naujas tyrimas rodo, kad vis daugiau žmoniu skursta [interaktyvus]. 2010 [žiūrèta 2012-02-18]. <http://europa.eu/rapid/press-release_IP-10-773_lt.htm?locale=en>. 
Kutzinas akcentuoja, kad teisumas nèra pakankamai įtrauktas ị šalių sveikatos priežiūros finansavimo sistemas ${ }^{6}$.

Prieš trylika metų (2000 m.) Pasaulio sveikatos organizacija parengè ataskaitą, kurioje buvo pateiktas integruotas sveikatos priežiūros finansavimo teisumo rodiklis, pagal kuri Lietuva atsidūrè 131-133 vietoje tarp PSO šalių narių ${ }^{7}$, tačiau dèl neaiškios skaičiavimo metodikos šio rodiklio vẻliau buvo atsisakyta. Viliaus Jono Grabausko teigimu, pagal sveikatos sistemos finansavimo teisumą Lietuva buvo priskirta ketvirtadaliui prasčiausiai besitvarkančių šalių ${ }^{8}$. Pasak Pasaulio sveikatos organizacijos, jei Europos Sąjungos šalys sumažintų neteisumą sveikatos priežiūros srityje 10 proc., tada būtų sutaupyta 18 milijardų eurų ir 6 milijardų eurų, kurių netektų išleisti atitinkamai sveikatos priežiūrai ir socialinio draudimo reikmèms?.

Problema. Šio darbo problemos aktualumą galima grịsti dviem probleminiais klausimais:

1. Kaip Lietuvos Respublikos teisès aktuose yra apibrèžtas teisumo principas, kuriuo turi būti vadovaujamasi finansuojant sveikatos priežiūrą?

2. Kaip finansuojant sveikatos priežiūrą Lietuvoje yra užtikrinamas teisumas, atsižvelgiant ì žmonių gebejjimo mokèti principą (mokumą)?

Darbo naujumas. Lietuvoje nei sveikatos politikai, nei kitų mokslo sričių atstovai nèra detaliai nagrinèję sveikatos santykių teisumo ir teisumo principo finansuojant sveikatos sistemą sampratos, igyvendinimo ir jo vertinimo. Sveikatos santykių teisumą bei teisumą finansuojant sveikatos priežiūrą daugiausia tyrinèjo užsienio šalių atstovai (Alexandra Bambas, Juan Antonio Casas, Göran Dahlgren, Margaret Whitehead, Adam Wagstaff, Eddy van Doorslaer ir kiti). Šio darbo tema Lietuvoje yra ne tik nauja, bet ir praktiškai aktuali. Išskirtinè priežastis, dèl kurios analizuojamas teisumas finansuojant sveikatos sistemą, naujumas.

Tyrimo objektas: teisumo principo finansuojant sveikatos sistemą vertinimas.

Tyrimo tikslas - sistemiškai apžvelgti teisumo, kaip svarbiausio sveikatos finansavimo principo, sampratą sveikatos politikoje ir išanalizuoti, ar Lietuvos teisès aktai reglamentuoja sveikatos santykių ir sveikatos priežiūros teisumą.

Tyrimo metodai: mokslinès literatūros ir teisinių dokumentų analizè, sintezè, lyginimo bei apibendrinimo.

\section{Termino „teisumas“ samprata}

Terminas „teisumas“ yra apibūdinamas kaip „garbumo, dorumo ir teisingumo apraiška“10.

$6 \quad$ Kutzin, J. Health financing policy: a guide of decision-makers. Health Financing Policy Paper, Division of Country Health Systems. WHO Regional Office for Europe Copenhagen, Denmark, 2008, p. 5.

7 World Health Report 2000. Health system: improving performance. WHO, Geneva, 2000.

8 Grabauskas, V. J. Lietuvos sveikatos priežiūra Europos Sąjungos ir pasaulio kontekste. Lietuvos sveikatos sektorius amžiu sandūroje. Vilnius: UAB Sveikatos ekonomikos centras, 2010, p. 89.

$9 \quad$ Kaip panaikinti atotrūki per vienos kartos gyvenamaji laikotarpi siekiant sveikatos santykiu teisumo per socialinius sveikatos veiksnius. Vilnius: Pasaulio sveikatos organizacijos biuras Lietuvoje, 2009, p. 2.

10 Lietuvių kalbos žodynas [interaktyvus]. [žiūrèta 2012-07-13]. <http://www.lkz.lt/startas.htm>. 
A. Bambas ir J. A. Casas terminą „teisumas“ apibrèžè kaip „prigimtinè teisé, laisvè nuo šališkumo ar tam tikrų interesų“, priešinga teisumo sąvokai yra terminas „neteisumas“ (angl. inequity) - „neteisingumas, šališkumas ar nesąžiningumas"11.

Terminai „teisumas“ (angl. equity) ir „lygybe“ (angl. equality) yra dažnai painiojami, nors yra skirtingi ir turi atitinkamai skirtingas reikšmes ${ }^{12},{ }^{13},{ }^{14},{ }^{15}$. Kaip ir buvo minèta, teisumas nurodo, kad kažkas yra skaidru, teisinga ar nešališka, o lygybè - vienodumą ${ }^{16},{ }^{17}$. Teisumu galima pasiekti lygybès ${ }^{18}$. Tačiau tam tikroje situacijoje ne visada lygus reiškia, kad yra teisingas, skaidrus ar sąžiningas, arba atvirkščiai - ne visi skirtumai yra neteisingi, neskaidrūs ar nesąžiningi $i^{19},{ }^{20}$. Teisumą ir neteisumą yra sunku ịvertinti, lyginant vien su netolygumais (angl. inequalities) ${ }^{21}$.

Taigi, mokslinèje literatūroje gausu termino „teisumas“ interpretacijų, jos priklauso nuo to, kokios mokslo šakos atstovas ją interpretuoja. Tai pažymi ir Pasaulio bankas teigdamas, kad terminas „teisumas“ yra vartojamas ịvairiuose kontekstuose, jo „skirtingos interpretaci-

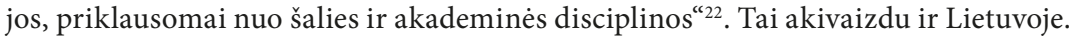

\subsection{Sveikatos santykių teisumas ir sveikatos priežiūros teisumas}

Teisumui sveikatos mokslų literatūroje apibūdinti yra vartojama sąvoka „sveikatos santykių teisumas“ arba kitaip „lygiateisiškumas sveikatos požiūriu“ (angl. health eguity, equity in health), o priešinga šiai sąvokai yra „sveikatos santykių neteisumas“ (angl. health inequity, inequity in health). Tačiau ir čia sveikatos santykių teisumo sąvoka yra apibrèžiama įvairiai.

Goranas Dahlgrenas ir Margaret Whitehead išskiria neteisybès sveikatos apsaugoje mažinimą, kuri tiesiogiai suponuoja neteisumą sveikatos priežiūroje, kaip vieną iš jos tiks$\operatorname{luc}^{23}$. Neteisumas sveikatos srityje gali atsirasti tarp visuomenès grupių ar tarp šalių ${ }^{24}$. Ichiro Kawachi ir bendraautoriai sveikatos santykių neteisumą apibūdina kaip netolygumus, kurie

11 Bambas, A.; Casas, J. Assessing Equity in Health: Conceptual Criteria. Equity \& Health. Washington: Pan American Health Organization, 2001, 8: 14.

12 Poteete, A. R. Is Decentralization a reliable mans of increasing equity? [interaktyvus]. New Orleans, Los Angeles, 2004, p. 4 [žiūrèta 2011-12-12]. <http://dlc.dlib.indiana.edu/dlc/bitstream/ handle/10535/2246/Poteete_Decentralization_and_Equity.pdf $>$.

13 Braveman, P.; Gruskin, S. Defining equity in health. Journal of Epidemiology \& Community Health [interaktyvus]. 2003, 57 [žiūrèta 2012-12-14]. <http://jech.bmj.com/content/57/4/254.full>.

14 Bambas, A.; Casas, J., supra note 11, p. 14.

15 Balancing Equity and Efficiency [interaktyvus]. [žiūrèta 2012-03-09]. <http://www.healthknowledge. org.uk/public-health-textbook/medical-sociology-policy-economics/4c-equality-equity-policy/ balancing-equity-efficiency $>$.

16 Poteete, A. R., op cit.

17 Bamba, A.; Casas, J., op cit., p. 14.

18 Poteete, A. R., op cit.

19 Bambas, A.; Casas, J., op cit., p. 14.

20 Braveman, P.; Gruskin, S., op cit.

${ }_{21}$ Kawachi, I., et al. A glossary for health inequalities. Journal of epidemiology and Community Health [interaktyvus]. 2002, 56 [žiūrèta 2013-03-12]. <http://jech.bmj.com/content/56/9/647.full>.

22 The World Bank, „Equity and Development“. World Development Report 2006. New York: Oxford University Press, 2006, p. 18.

23 Dahlgren, G.; Whitehead, M. Policines and strategies to promote equity in health. WHO, Copenhagen, 1992, p. 7.

24 World Health Organization. Social determinants of health [interaktyvus]. [žiūrèta 2013-03-12]. $<$ http://www.who.int/social_determinants/thecommission/finalreport/key_concepts/en/index.html >. 
yra nesąžiningi ar kylantys iš tam tikrų neteisingumo formų ${ }^{25}$. Sveikatos santykių neteisumas yra susijęs ir su sveikatos netolygumais, kurie yra politiškai, socialiai ir ekonomiškai nepriimtini ${ }^{26}$ ir dèl kurių yra apribojami asmens pasirinkimai bei galimybės kontroliuoti veiksnius, galinčius turèti įtakos sveikatai ${ }^{27}$. Neteisumo galima išvengti arba ji pataisyti per tikslingus žmogaus veiksmus ${ }^{28}$.

Sveikatos santykių teisumas reiškia, kad visi turi lygias galimybes siekti didžiausio sveikatos potencialo ir niekas negali sudaryti šiam siekimui nepalankių sąlygų $u^{29},{ }^{30}$. M. Whitehead ir Henkas Leenanas sveikatos santykių teisumą apibūdina taip pat kaip žmonių lygias galimybes siekti sveikatos bei pažymi, kad negali būti sveikatos priežiūros skirtumų ${ }^{31},{ }^{32}$. Paula Braveman ir Sofia Gruskin sveikatos santykių teisumą apibūdina kaip „sistemingų skirtumų nebuvimą sveikatos srityje (ar sveikatą lemiančių veiksnių) tarp ịvairių socialinių grupių“33, o M. Whitehead yra pasakiusi, jog „sveikatos santykių skirtumai yra nereikalingi ir išvengiami, be to, jie yra nesąžiningi ir neteisingi “34.

Sveikatos santykių teisumas turi etinę reikšmę, kuri grindžiama socialinio teisingumo ir žmogaus teisių principais ${ }^{35}$. P. Braveman ir S. Gruskin taip pat teigia, kad sveikatos santykių teisumas glaužiai yra susijęs su žmogaus teisès sąvoka ${ }^{36}$.

Sveikatos santykių teisumas apibūdina ir skaidrius paskirstymus tarp populiacijos, nuo kurių priklauso ir sveikatos rezultatai. Richardas Kleinas ir Davidas Huangas sveikatos santykių teisumą apibūdina kaip sveikatą lemiančių veiksnių, rezultatų ir išteklių (pvz.: sveikatos draudimo, švietimo, švaraus oro ir kt.) skaidrų pasiskirstymą populiacijose, nepriklausomai nuo socialinės padèties ${ }^{37}$. Tokios pačios nuomonès yra P. Braveman ir S. Gruskin kalbėdamos apie sveikatos santykių teisumą - jų nuomone, sveikatos santykių teisumas api-

$25 \quad$ Kawachi, I., et al., supra note 21.

26 World Health Organization. The world health report [interaktyvus]. [žiūrèta 2013-02-27]. <http:// www.who.int/whr/2008/overview/en/index.html>.

27 Picavet, H. S. J. Perspectives on Health Inequity. Harris E., Sainsbury S., Nutbeam D. editors. Sydney: The Australian Centre for Health Promotion, 1999.

28 Commission on social determinants of health, Towards a Conceptual Framework for Analysis and Action on the Social Determinants of Health, Discussion paper for the Commission on Social Determinants of Health, 2005, p. 5.

29 Social justice and equity in health: report on a WHO meeting (Leeds, United Kingdom, 1985). Copenhagen, Regional Office for Europe, 1986 (ICP/HSR804/m02).

30 World Health Organization. The Solid Facts: Social Determinants of Health. Copenhagen: World Health Organization, 1998, 7th edt., p. 6-7.

31 Whitehead, M. The concepts and principles of equity and health. World Health Organization Regional Office for Europe Copenhagen, 1990, p. 5.

32 Leenan, H. Equality and equity in health care. Paper presented at the WHO/Nuffield Centre for Health Service Studies meeting. Leeds, 1985.

33 Braveman, P.; Gruskin, S., p. Defining equity in health, supra note 13, 254-254.

34 Whitehead, M. The concepts and principles of equity and health. International Journal of Health Service. 1992, p. 429-445.

35 International Society for Equity in Health [interaktyvus]. [žiūrèta 2013-01-20]. <http://www.iseqh. org/>.

36 Braveman, P.; Gruskin, S. Poverty, equity, human rights and health. Bulletin of the World Health Organization. 2003, p. 540.

37 Klein, R.; Huang, D. Defining and measuring disparities, inequities, and inequalities in the Healthy People initiative. National Center for Health Statistics Centers for Disease Control and Prevention [interaktyvus]. [žiūrèta 2012-01-05]. <http://www.cdc.gov/nchs/ppt/nchs2010/41_Klein.pdf>. 
ma išteklių paskirstymą ir kitus procesus, nuo kurių priklauso, ar bus sveikatos netolygumai tarp skirtingų socialinių grupių, ar jų nebus ${ }^{38}$.

Mamdouh Gabras skiria du požiūrius, kuriais galima siekti teisumo, - „solidarumo požiūris“, kuriame pagrindinis dèmesys skiriamas visuomenei, kaip visumai, tačiau gali būti skiriamas didesnis dèmesys kai kuriems visuomenès narių arba jų grupių poreikiams. Kitu požiūriu yra išskiriamas „asmeninès teisès požiūris“, pagal kurị kiekvienas asmuo turi turèti vienodas galimybes naudotis sveikatos priežiūros paslaugomis ir gauti vienodą sveikatos rezultatą ${ }^{39}$.

Vadovaujantis teisumo principu skiriamas dėmesys labiausiai pažeidžiamų žmonių sveikatai $^{40}$. Sveikatos santykių teisumu siekiama pagerinti sveikatą tiems, kurių nepalanki socialinè ar ekonominè padètis (sveikatos skirtumų mažinimas sveikatos priežiūros srityje, gyvenimo ir darbo sąlygų vienodinimas) ${ }^{41}$. Tai patvirtina ir G. Dahlgrenas ir M. Whitehead, kurie sveikatos santykių teisumo siekị apibrèžia kaip sveikatos skirtumų panaikinimą tarp ivvairių socialinių ir ekonominių grupių ${ }^{42}$.

Georgi Shakarishvili teisumo sąvoką îvardina kaip neaiškią ir pažymi, kad teisumą yra sunku ịvertinti ${ }^{43}$. Pasak G. Shakarishvili bei Timothy Evanso ir jo bendraautorių, sveikatos santykių teisumas yra susijęs su sveikatos būklès rodikliais - jų teigimu, sveikatos santykių teisumas pasiekiamas, kai pagrindiniai sveikatos būklès rodikliai, sergamumo ir mirtingumo rodikliai bei jų tendencijos yra panašios visose grupèse, kurios skiriasi socialine ekonomine, etnine, tautybès, lyties, geografine padètimi ${ }^{44},{ }^{45}$.

M. Whitehead teigia, kad nagrinejjant teisumą kyla daug diskusijų, kadangi vieni nagrinèja netolygumų lygị ir sveikatos būklę skirtingose populiacijos grupèse, o kiti - sveikatos priežiūros paslaugų teikimo ir skirstymo netolygumų lygị. Skirtumai paprasčiausiai gali būti ịvertinti analizuojant sveikatos statistiką. Tačiau svarbu žinoti, kad ne visi skirtumai gali būti ivardijami kaip netolygumai ${ }^{46}$.

Pasak A. Bambaso ir J. A. Casaso, teisingas gèrybių, kurios lemia sveikatos būklę, paskirstymas turi atitiki šiuos kriterijus ${ }^{47}$ :

- turi būti išvengiama paskirstymų skirtumų,

- neturi atsispindèti laisvas pasirinkimas,

- tai turi būti padaryta atsakingai.

38 Braveman, P.; Gruskin, S. Defining equity in health, supra note 13, p. 57.

39 Gabr, M. Health Ethics, Equity and Human Dignity [interaktyvus]. [žiūreta 2013-02-09]. <http://www. humiliationstudies.org/>.

$40 \quad$ Ibid.

${ }^{41}$ Secretary's Advisory Committee on National Health Promotion and Disease Prevention Objectives for 2020, Revised definitions for health disparities and health equity [interaktyvus]. [žiūrèta 2013-01-07]. $<$ http://healthypeople.gov/2020/about/advisory/FACA6Minutes.aspx?page=2>.

42 Dahlgren, G.; Whitehead, M. Concepts and principles for tackling social inequities in health: Levelling up Part 1, WHO European Office for Investment for Health and Development, 2006, p. 12.

43 Shakarishvili, G. Poverty and Equity in Healthcare Finance: Analyzing Post-Soviet Healthcare Reform. Hungary, 2006, p. 6.

44 Evans, T., et al. Challenging Inequalities in Health: from ethics to action. Oxford: Oxford University Press, 2001, p. 68-75.

45 Shakarishvili, G., op cit., p. 6.

${ }_{46}$ Whitehead, M. The concepts and principles of equity and health, supra note 31, p. 4.

47 Bambas, A.; Casas, J., supra note 11, p 17. 
Williamas C. Hsiao ir Yuanli Liu sveikatos priežiūros teisumą apibūdina trumpu apibrèžimu - „vienodas naudojimasis sveikatos priežiūra“48.

Užsienio ša lių literatūroje sąvoka „sveikatos priežiūros teisumas“ gana daugialypè: jai suteikiama prieinamumo, finansų, išlaidų, kokybės, sveikatos rizikos apsaugos, sveikatos būklès ir kitos prasmès.

Teisumas apima procesą ir rezultatus. Svarbu yra ịvertinti konkrečių spendimų poveikị teisumui ir siekti, kad priimami sprendimai didintų teisumą ${ }^{49}$.

Kaip minėta, G. Shakarishvili teisumo savoką ịvardino kaip neaiškią, tačiau jo nuomone, teisumas rūpinantis sveikatos priežiūra yra susijęs su prieinamumu, finansavimu ir sveikatos priežiūros paslaugų kokybe ${ }^{50}$.

Štai Anne Drouin sveikatos priežiūros teisumą apibūdina 4 skirtingais lygiais: „,sveikatos priežiūros finansavimo teisumas, sveikatos priežiūros prieinamumo teisumas, sveikatos būklès teisumas ir sveikatos rizikos apsaugos teisumas" ${ }^{\text {"51. }}$.

Pasak T. Evanso ir bendraautorių, sveikatos priežiūros teisumas yra susijęs su sveikatos priežiūros aprūpinimu (įskaitant prieinamumą), sveikatos priežiūros finansavimu ir sveikatos priežiūros paslaugų kokybe. Jų nuomone, sveikatos priežiūros paslaugų teikimo teisumas yra iggyvendinamas, kai vienodą poreikị turintys asmenys gauna atitinkamai vienodą priežiūrą ${ }^{52}$.

H. Leenanas sveikatos priežiūros teisumą apibūdina taip ${ }^{53}$ :

- Vienodas sveikatos priežiūros prieinamumas, turintiems vienodus poreikius.

- Vienodas naudojimasis sveikatos priežiūra, turint vienodus poreikius.

- Vienoda sveikatos priežiūros kokybè.

M. Gabras sveikatos požiūriu teisumą apibrèžia taip ${ }^{54}$ :

- Vienodas sveikatos priežiūros išteklių paskirstymas kiekvienam individui.

- Vienodas sveikatos priežiūros prieinamumas.

- Vienoda sveikatos priežiūros kokybè.

- Vienoda sveikatos būklè.

- Vienodas sveikas gyvenimo būdas už išeikvotus pinigus (pvz.: už 1 dolerị).

- Sveikatos priežiūra pagal poreikị.

Pasak Danielio Lypezo Acuca, sveikatos priežiūros teisumo reikia siekti per tris komponentus ${ }^{55}$ :

${ }_{48}$ Hsiao, W. C.; Liu, Y. Health Care Financing: Assessing Its Relationships to Health Equity, Equitable Health Care System, Challenging Inequities in Health, from Ethics to Action, New York: Oxford University Press, 2001, p. 270.

49 Gabr, M., supra note 39.

50 Shakarishvili, G., supra note 43, p. 6.

51 Drouin, A. Methods of financing health care: A rational use of financing mechanisms to achieve universal coverage. Technical Commission on Statistical, Actuarial and Financial Studies. Geneva: International Social Security Association, 2007, p. 2-3.

52 Evans, T., et al. Challenging Inequalities in Health: from ethics to actio. Oxford: Oxford University Press, 2001, p. 68-75.

53 Leenan, H. Equality and equity in health care. Paper presented at the WHO/Nuffield Centre for Health Service Studies meeting. Leeds, 1985.

54 Gabr, M., supra note 39.

55 Acuca, D. L., et. al. Access to and Financing of Health Care: Ways to Measure Inequities and Mechanisms to Reduce Them. Equity \& Health. Pan American Health Organization, 2001, p. 117. 
- „Poreikiais pagrịstas sveikatos priežiūros paslaugų teikimas - sveikatos priežiūros paslaugos turi būti teikiamos pagal poreikius, nepriklausomai nuo lyties, amžiaus, gebèjimo mokèti, etniškumo, kultūros ar gyvenamosios vietos.

- Nuolatinis išteklių skirstymo efektyvumo siekimas - kuo didesnè sveikatos priežiūros nauda skirstant išteklius, atsižvelgiant ị epidemiologinę situaciją ir sąnaudų veiksmingumą („už turimus pinigus sukuriama didžiausia vertë).

- Nuolatinis techninio efektyvumo siekimas - turimi ištekliai turi užtikrinti kuo geresnị paslaugų teikimą, atsižvelgiant ị žmonių poreikius.“

Mattias Lundberg ir Limin Wang sveikatos priežiūros teisumą apibūdina per prieinamumą, finansavimą, išlaidas ir sveikatos būklę bei pažymi, kad sveikatos politikoje yra išskiriamas horizontalus ir vertikalus teisumas, kuris turi tam tikras reikšmes kiekvienu atveju (žr. 1 lentelę) $)^{56}$.

1 lentelè. Sveikatos priežiūros teisumo samprata sveikatos politikoje

\begin{tabular}{|c|c|c|}
\hline \multirow{2}{*}{$\begin{array}{l}\text { Teisumo } \\
\text { aspektas }\end{array}$} & \multicolumn{2}{|c|}{ Teisumo samprata } \\
\hline & Horizontalus & Vertikalus \\
\hline Prieinamumas & $\begin{array}{l}\text { Asmenys, kurių vienodi poreikiai, turi } \\
\text { vienodą sveikatos priežiūros prieina- } \\
\text { mumą }\end{array}$ & $\begin{array}{l}\text { Asmenys, kurių didesni poreikiai, turi } \\
\text { didesnị sveikatos priežiūros prieina- } \\
\text { mumą }\end{array}$ \\
\hline Finansavimas & $\begin{array}{l}\text { Asmenys, kurių socialiné ekonominé } \\
\text { padètis vienoda, už sveikatos priežiūrą } \\
\text { moka tiek pat }\end{array}$ & $\begin{array}{l}\text { Turtingesnis namų ùkis moka daugiau } \\
\text { už sveikatos priežiūrą nei skurdesnis } \\
\text { namų ūkis }\end{array}$ \\
\hline Išlaidos & $\begin{array}{l}\text { Asmenys, kurių socialinè ekonominè } \\
\text { padètis vienoda ar panaši sveikatos } \\
\text { būklè, gauna tokią pačią valstybès fi- } \\
\text { nansuojamą sveikatos priežiūrą }\end{array}$ & $\begin{array}{l}\text { Skurdesni ar turintys daugiau sveikatos } \\
\text { problemų namų ùkiai gauna didesnę } \\
\text { sveikatos priežiūrą nei turtingesni ir } \\
\text { sveikesni namų ūkiai }\end{array}$ \\
\hline Rezultatai & \multicolumn{2}{|c|}{$\begin{array}{l}\text { Namų ùkių sveikatos rezultatai panašūs, nepriklausomai nuo socialinės ekonomi- } \\
\text { nės padèties }\end{array}$} \\
\hline
\end{tabular}

Šaltinis: Lundberg, M.; Wang, L. Health sector reforms. 2006, p. 49

M. Lundbergas ir L. Wangas horizontalų teisumą apibūdina kaip „išlaidų ir naudos paskirstymą tarp grupès žmonių, kurių panaši ekonominè socialinė padètis ir sveikatos būklë“, o vertikalų teisumą - kaip „skirtingą išlaidų ir naudos paskirstymą tarp grupės žmonių, kurių skirtinga padètis“57. Pasak Stepheno Moriso ir bendraautorių, „vertikalus teisumas parodo, jog asmenys, turintys skirtingus poreikius, gauna ir skirtingą sveikatos priežiūrą"58. Vertikalus teisumas glaudžiai susijęs su solidarumo principu, kadangi vargingesniems žmonèms turi būti sudaromos palankesnès sąlygos siekti sveikatos.

56 Lundberg, M.; Wang, L. Health sector reforms. Analyzing the Distributional Impact of Reforms. The World Bank, 2006, p. 48.

57 Lundberg, M.; Wang, L., ibid, p. 49.

58 Morris, S., et al. Inequity and inequality in the use of health care in England: an empirical investigation. Social Science and Medicin. 2005, p. 1251. 
Horizontaliu ir vertikaliu lygiu yra skirtingai apibūdinamas sveikatos priežiūros prieinamumo, finansavimo ir išlaidų teisumas, tačiau siekiami sveikatos rezultatai neturi skirtis jie turi būti vienodi ar bent jau panašū $\mathrm{s}^{59}$.

„Nors neteisumas sveikatos priežiūros srityje nèra naujas reiškinys, jo galima išvengti, o susiklosčiusią situaciją galima pakeisti imantis veiksmų socialinèje, politinejje ir ekonominèje srityse. "60

Apibendrinant sveikatos santykių teisumo sąvoką galima apibūdinti kaip sudètinę žmoniu lygias galimybes siekti sveikatos bei gauti vienodus sveikatos rezultatus per skaidrius ¡vairiu ištekliu paskirstymus, nepriklausomai nuo socialinès ir ekonominès padèties.

Išnagrinèjus sveikatos priežiūros teisumo sampratas matyti, jog mokslinèje literatūroje daugiausia dèmesio skiriama sveikatos priežiūros prieinamumui, kokybei ir sveikatos būklès rezultatams. Sveikatos priežiūros kokybès užtikrinimas turi būti vienodas visiems, prieinamumas - vienodas tiems, kurie turi vienodus poreikius, o sveikatos būklè - vienoda visose visuomenès grupése, nepriklausomai nuo socialinès ekonominès padèties.

\subsection{Teisumas finansuojant sveikatos priežiūrą}

Sveikatos priežiūros finansavimas turi dvi sampratas. Viena iš jų - finansavimas susijęs tik su sveikatos priežiūros léšų sutelkimu, kita - finansavimas apima lèšų sutelkimą sveikatos priežiūrai, lešų paskirstymą regionams, tam tikroms gyventojų grupèms, sveikatos priežiūrai bei mokejjimų už sveikatos priežiūrą mechanizmus ${ }^{61}$.

Daugelis šalių finansuojant sveikatos priežiūrą naudoja ịvairius įmokų šaltinius: bendruosius mokesčius, socialinio draudimo i̇mokas, privačias sveikatos draudimo įmokas, bendruomeninị finansavimą, tiesioginius pacientų mokèjimus ${ }^{62},{ }^{63}$.

W. C. Hsiao ir Y. Liu teigimu, „teisumo požiūriu sveikatos sistemos finansavimas svarbus dèl dviejų priežasčių: lemia sveikatos priežiūros paslaugų prieinamumą ir užtikrina finansinès apsaugos nuo katastrofinių išlaidų ir susirgimų laipsnị “64.

Diana De Graeve teisumą finansuojant sveikatos priežiūrą apibūdina kaip skaidrų mokèjimų už sveikatos priežiūrą paskirstymą tarp populiacijos. „Kas moka ir kiek moka?“ - tai pagrindiniai klausimai, kurių pagrindu diskutuojama apie teisumu grindžiamą sveikatos sistemos finansavimą ${ }^{65}$. D. D. Graeve ir W. C. Hsiao ir Y. Liu analizuodami teisumą finansuojant sveikatos priežiūrą išskiria klausimą - „kas sumokejjo mokesčius ar įmokas ị sveikatos sistemą?“ bei papildo analizę dar vienu klausimu - „ar taikomas finansavimo modelis yra teisingas?"“. W. C. Hsiao ir Y. Liu šiuos klausimus užduoda nagrinèdami finansavimą siaurąja prasme $^{66}$. Finansavimo modelị apibūdina ir A. Bambas ir J. A. Casas sutelkdami dèmesị ties klausimu - „o kokiais būdais sveikatos priežiūra yra finansuojama atsižvelgiant ị gebejjimą mokèti?" ${ }^{\prime 67}$.

59 Lundberg, M.; Wang, L., supra note 56, p. 49.

60 Kaip panaikinti atotrūki per vienos kartos gyvenamaji laikotarpi siekiant sveikatos santykiu teisumo per socialinius sveikatos veiksnius, supra note 9, p. 3.

${ }_{61}$ Hsiao, W. C.; Liu, Y., supra note 48, p. 261.

62 Hsiao, W. C.; Liu, Y., ibid., p. 261.

63 Drouin, D., supra note 51, p. 2.

64 Hsiao, W. C.; Liu, Y., op. cit., p. 261.

65 Graeve, D. D.; Xu, K. Health Finance, Equity. Health System Policy, Finance and Organization. Carrin G., editor. 2008, p. 195.

66 Hsiao, W. C.; Liu, Y., op cit., p. 261.

67 Bambas, A.; Casas, J., supra note 11, p. 14. 
Nagrinejjant plačiau teisumą finansuojant sveikatos priežiūrą, dažniausiai diskutuojama, kiek sveikatos sistemos finansavimas yra nutolęs nuo gebejjimo mokèti ${ }^{68}$. Sveikatos sistemos finansavimo mechanizmas turi atitikti gebejimo mokèti principą $a^{69},{ }^{70},{ }^{71}$. Teisumas, atsižvelgiant ì gebejjimo mokèti principą, gali būti nagrinejjamas dviem bùdais ${ }^{72},{ }^{73},{ }^{74},{ }^{75},{ }^{76}, 77$ :

- Vertikalus sveikatos priežiūros finansavimo teisumas - reiškia, kad žmonès, turintys skirtingas galimybes mokèti, moka skirtingai. Vertikalaus teisumo atveju, augant mokesčio mokètojo pajamoms, vis didesnè jų dalis turètų būti skiriama mokesčiams. Vertikalus teisumas atspindi mokesčius, kurie yra progresiniai, - kuo didesnès pajamos, tuo didesni mokesčiai.

Vertikalus sveikatos priežiūros finansavimo teisumas yra glaudžiai susijęs su solidarumo principu, kadangi siekiama sudaryti palankias mokèjimo sąlygas vargingesniems žmonėms, kad jie nebūtų nuskriausti.

- Horizontalus sveikatos priežiūros finansavimo teisumas - teisumas egzistuoja tada, kai žmonių grupès, turinčios vienodas galimybes mokèti, moka tiek pat.

Horizontalus teisumas yra apibūdinamas kaip etinis principas, kai suteikiamos vienodos sąlygos žmonėms, turintiems vienodas sveikatos problemas, t. y. nėra diskriminacijos, kaip, kiek ir kokių priežiūros paslaugų turètų būti suteikta. Todèl horizontalus teisumas apima vienodą veiksmingumą. „Horizontalus teisumas ir sąnaudų efektyvumas yra puikiai suderinami tol, kol išlaidos yra vienodas arba panašios, nes tada gydymo sąnaudų efektyvumas yra vienodas pacientams, turintiems vienodas problemas. Kitokia situacija yra, kai pacientų gydymo išlaidos labai skiriasi, tada teisumas ir efektyvumas tarpusavyje prieštarauja "78.

Pasak Christopherio J. L. Murray ir Julio Frenko, kad sveikatos sistemos finansavimas būtų pagrịstas teisumu, turi būti išspręsti du uždaviniai ${ }^{79}$ :

1. „Namų ūkiai neturètų skursti - pernelyg didelę savo pajamų dalị skirti reikiamų sveikatos priežiūros paslaugų apmokejimui. Kitaip sakant, finansinių įnašų teisumas atskiruose namų ūkiuose yra priemonè sveikatos finansavimo rizikai sumažinti.

68 Wagstaff, A. J.; van Doorslaer, E. Equity in Health Care Financing and Delivery. North Holland Handbook of Health Economics. Culyer A. J., Newhouse J. P., editors, 1998, p. 16.

69 van Doorslaer, E.; O'Donnell, O. Measurement and Explanation of Inequality in Health and Health Care in Low-Income Settings. UNU-WIDER World Institute for Development Economics Research, 2008, p. 2.

70 Hurst, J. W. Reforming health care in seven European nations. Health Affairs. 1991, 10(3): 7.

${ }^{71}$ Gottschalk, P. et al. Health care financing in U.S., U.K. and Netherlands: distributional consequences, Changes Revenue Structures, Detroit: Wayne State University Press, p. 351-373.

72 Bambas, A.; Casas, J., supra note 11, p. 14.

73 Wagstaff, A. J.; van Doorslaer, E. Equity in the finance of health care: some international comparisons. Journal of health economics. 1992, p. 371.

74 Wagstaff, A. J.; Van Doorslaer, E. Equity in Health Care Financing and Delivery, supra note 68, p. 16.

75 Wagstaff, A. J., et al. Equity in the finance and delivery of health care: some tentative cross-country comparisons. Oxford review of economic policy. 1989, 5(1): 93-94.

76 George, A. O. Alleyne, „Equity and Health“. Equity \& Health. Washington: Pan American Health Organization, 2001, 8: 8.

77 Hsiao, W. C.; Liu, Y., supra note 48, p. 266.

78 Musgrove, P. Health economics in development. Washington: The World Bank, 2004, p. 174-175.

79 Murray, C. J. L.; Frenk, J. A framework for assessing the performance of health systems. Bulletin of the World Health Organization. 2000, 78(6): 720. 
2. „Vargingai gyvenančios šeimos turètų mokèti mažiau ị sveikatos sistemą nei turtingi namų ūkiai. Inašai ị sveikatos sistemą turètų atspindèti disponuojamų pajamų skirtumus tarp turtingųjų ir vargšų.

Siekiant teisingesnio finansinès naštos paskirstymo sveikatos sistemoje - finansavimo teisumu siekiama, kad turtingesni žmonès mokètų didesnę savo pajamų dalị už sveikatos priežiūrą nei neturtingesni žmonès." ${ }^{80}$

Kai kalbama apie sveikatos priežiūros finansavimo ir išlaidų teisumą, svarbus yra toks finansavimo metodas, kuriuo siekiama sveikatos rezultatų ir žmonių gerovès teisumo. Yra daug būdų, nuo kurių priklauso sveikatos priežiūros finansavimo ịtaka sveikatos priežiūros prieinamumui, paskirstymui ir veiksmingumui. Tai iliustruota 1 paveiksle ${ }^{81}$.

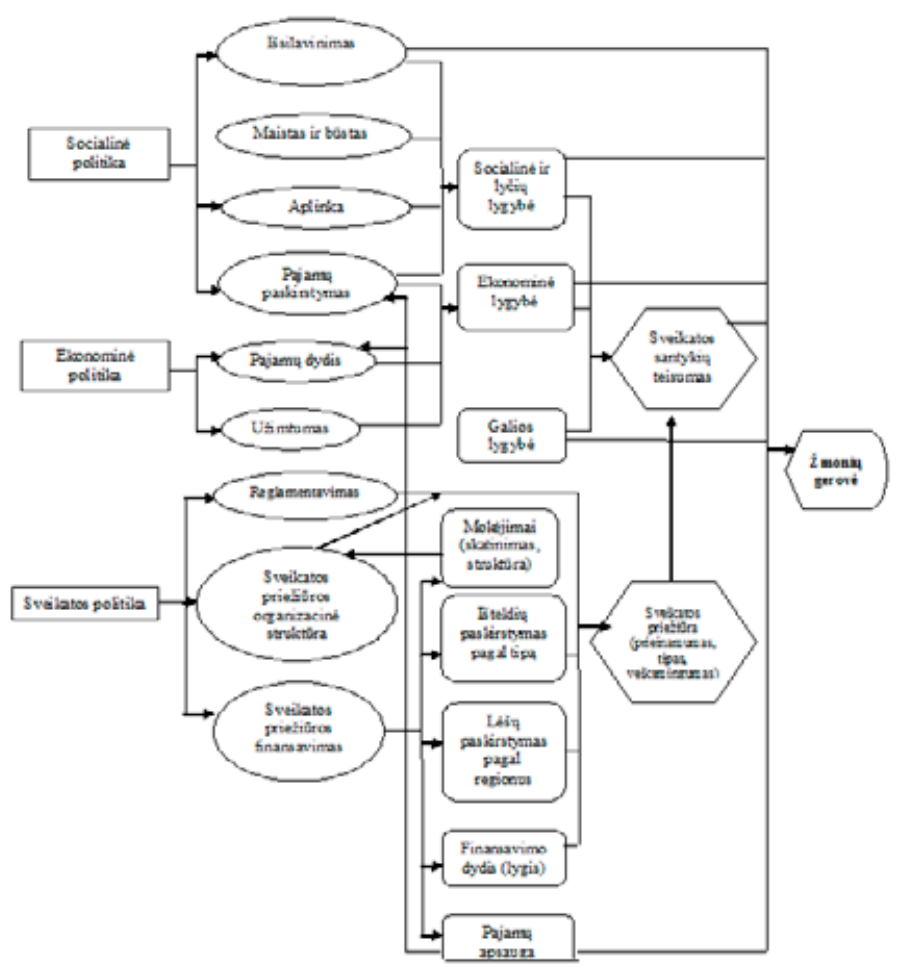

Šaltinis: Hsiao, W. C.; Liu, Y. Health Care Financing: Assessing Its Relationships to Health Equity, Equitable Health Care System. 2001, p. 264

1 pav. Ryšys tarp sveikatos priežiūros finansavimo ir sveikatos santykių teisumo plačiąja prasme

80 Thomson, S., et al. Financing health care in the Europian Union: challenges and policy responses. Copenhagen: WHO Europe on behalf of the European Observatory on Health Systems and Policies, 2009 , p. 25.

81 Hsiao, W. C.; Liu, Y., supra note 48, p. 263. 
Šioje schemoje parodytas ne tik sveikatos politikos, bet ir socialinès bei ekonominès politikos galutinis tikslas - žmonių gerovè. Schemoje parodyta, kad žmonių gerovẻ priklauso nuo socialinès ir ekonominès politikos (išsilavinimo, pajamų, aplinkos sąlygų, pajamų apsaugos ir kt.). Sveikatos priežiūros paslaugų paskirstymas, prieinamumas bei žmonių finansinè apsauga prisideda prie teisumo sveikatos sistemoje. Sveikatos priežiūra prisideda ir prie žmonių gerovès. Be to, sveikatos priežiūros finansavimas yra vienas iš daugelio veiksnių, stiprinančių sveikatos santykių teisumą. Finansavimo schema taip pat norima parodyti, kiek pinigų bus sutelkta, kaip lěšos bus naudojamos ir valdomos, kaip efektyviai, kokios bei kam paslaugos bus prieinamos ${ }^{82}$.

J. Kutzinas sveikatos sistemos finansavimą apibūdina kaip vieną iš keturių sveikatos sistemos funkcijų. Iš tarpinių sveikatos finansavimo politikos tikslų jis išskiria teisumą naudojantis sveikatos priežiūros paslaugomis ir paskirstant išteklius. Sveikatos finansavimo politikos tikslai yra naudojami kaip kriterijai nustatant sveikatos sistemos finansavimo teisumą (žr. 2 pav. $)^{83}$.

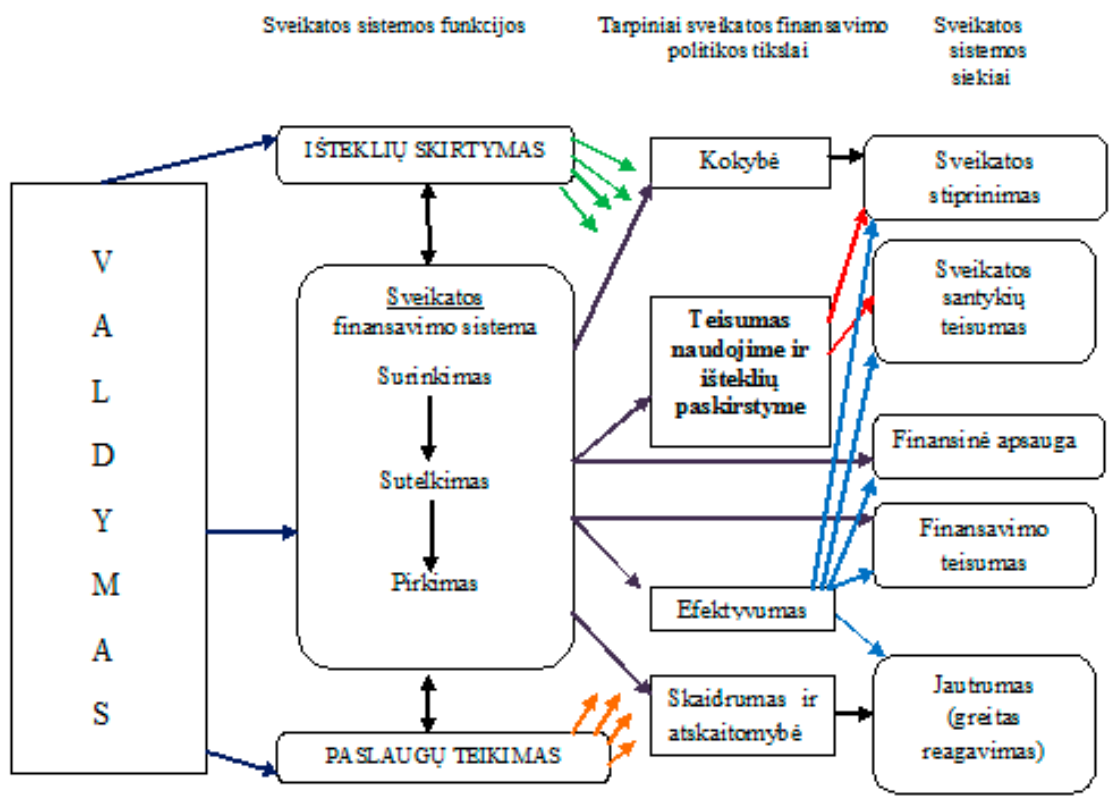

Šaltinis: Kutzin, J. Health financing policy: a guide of decision-makers. 2008, p. 77

2 pav. Naudojimo ir išteklių paskirstymo teisumas Reikètų pataisyti pav.: Išteklių skirstymas (praleista s); Teisumas naudojime ir išteklių paskirstyme= Teisumas naudojant ir paskirstant išteklius

J. Kutzinas, kaip jau aptarta, pažymi, kad sveikatos sistema turi būti finansuojama vadovaujantis teisumu - atsižvelgiant ì gebejjimą mokèti - vargšas neturi mokèti daugiau

82 Hsiao, W. C.; Liu, Y., supra note 48, p. 263.

83 Kutzin, J., supra note 6, p. 3. 
negu turtingas. Tačiau jo požiūriu, „teisumas naudojantis sveikatos priežiūros paslaugomis apibūdina sveikatos paslaugų paskirtymą pagal poreikị, o ne pagal kitus veiksnius, tokius kaip žmonių gebejjimą susimokèti už paslaugas" ${ }^{\text {84 }}$. Tam pritaria Reinholdas Gruenas ir Anne Howath - jų teigimu, „teisumas naudojantis sveikatos priežiūros paslaugomis reiškia, kad turi būti taikomos vienodos sąlygos vienodiems poreikiams, nepriklausomai nuo gebejimo mokèti, amžiaus, lyties, etniškumo, religijos ir geografinès padèties " ${ }^{\text {"85 }}$.

Pagrindinè teisumo problema skirstant sveikatos priežiūros lěšas - paskirstyti sveikatos priežiūros lèšas, kad nè vienas nebūtų nuskriaustas ${ }^{86}$. R. Gruenas ir A. Howath atkreipia dèmesị ị sveikatos priežiūros finansavimo teisumą - jų nuomone, jis svarbus dèl „teisingos finansinès naštos paskirstymo, kuri paprastai yra pasiekiama per progresyvinị apmokestinimą ar progresyvinius socialinio draudimo įmokų tarifus ${ }^{\text {"877. }}$.

Yra keletas autorių, kurie teigè, kad sveikatos priežiūros finansavimo teisumas turi būti vertinamas grynąja nauda ${ }^{88}, 89$.

D. De Graeve skiria du metodus, kurie plačiai taikomi įvertinant sveikatos sistemos finansavimo teisumą, - pajamu metodas ir finansinés naštos metodas. „Pajamų metodas yra išvedamas iš visuomenès finansų vertinimo teisumo, kur progresyvumas yra pagrindinis rodiklis. Šis metodas plačiausiai buvo taikomas Ekonominio bendradarbiavimo ir plètros organizacijos šalyse. Finansinès naštos metodu mokejjimo už sveikatos priežiūrą našta turi būti tolygiai paskirstyta visiems namų ūkiams. Abu metodai papildo vienas kitą ir vadovaujasi principu, kad léšos sveikatos priežiūrai turi būti skiriamos atsižvelgiant ị gebejjimą mokèti. " 90

Analizuodami sveikatos sistemos veiklos įvertinimo metodologiją, Ch. J. L. Murray ir J. Frenkas pateikia tris pagrindinius sveikatos sektoriaus tikslus, kurie apima ne tik gyventoju sveikatinimą, gyventojų lūkesčių, apimančių ịvairius sveikatinimo veiklos aspektus, patenkinimą, bet ir teisingo finansavimo mechanizmo igyvendinimą. Pasak šių autorių, „teisingo finansavimo kriterijus - tai teisingų sveikatos priežiūros sistemos ekonominių santykių igyvendinimas, vienodai paskirstant sveikatos priežiūros finansavimo ekonominị ịnašą, tenkantị įvairioms gyventojų grupèms" ${ }^{\text {"91 }}$.

Apibendrinus sveikatos priežiūros finansavimo teisumą, galima ịvardinti šiuos sveikatos sistemos finansavimo aspektus, nuo kurių priklauso teisumo principo igyvendinimas: taikomas sveikatos sistemos finansavimo modelis, finansuotojai ir jų finansavimo apimtys. Finansuojant sveikatos priežiūrą turi būti vadovaujamasi teisumu, kurio pagrindas - gebejimo mokèti principas.

$84 \quad$ Kutzin, J., supra note 6, p. 5.

85 Gruen, R.; Howath, A. Managing health services finance. 2005, p. 14.

86 Jakutytè, S. Teisingumo teorijos taikymas sveikatos priežiūroje: galimybès ir ribos [interaktyvus]. 2001, p. 4 [žiūrèta 2012-02-04]. <www.ebiblioteka.lt/resursai/LMA/Filosofija/F-03.pdf>.

87 Gruen, R.; Howath, A., op cit., p. 14.

88 Zschock, D. K. Health sector disparities in Peru. Bulletin of the Pan American Health Organization. 1989, 23(3): 323.

89 Hoare, G.; Mills, A. Paying for the Health Sector: A Review and Annotated Bibliography of the Literature on Developing Countries. Evaluation and Planning Center for Health Care. London: London School of Hygiene and Tropicla Medicine, 1986, 12.

90 Graeve, D. D.; Xu, K., supra note 65, p. 196.

91 Murray, C. J. L.; Frenk, J., supra note 79, p. 720-721. 


\section{Teisumo principas Lietuvos sveikatos priežiūros teisinio reguliavimo srityje}

Lietuvos teisès aktuose teisumo samprata glaudžiai siejasi su lygybès ir teisès kontekstais. Sveikatos santykiu teisumas yra apibūdintas šiuose Lietuvos teisés aktuose ir dokumentuose:

1. Lietuvos sveikatos programoje vienas iš trijų pagrindinių tikslų, kuriuo siekiama sumažinti sveikatos skirtumus, yra „sveikatos santykių teisumas“. Jis ịvardintas kaip pagrindinis tikslas ir apibūdintas taip: „kiekvienas asmuo turi teisę siekti kuo geresnès sveikatos. Bet sveikatos santykių teisumas reiškia, kad kiekvienas asmuo, siekdamas išsaugoti savo sveikatą, nepažeistų tokių pačių kito asmens teisių arba nesiektų šios teisès kito asmens ar visuomenès sąskaita. Todèl sveikatos santykių teisumas yra susijęs su lygiomis galimybėmis siekti sveikatos ir su maksimaliu skirtumų tarp jos siekiančiųjų sumažinimu. ${ }^{" 92}$

2. Lietuvos Respublikos Seimo nutarime „Dèl Lietuvos sveikatos sistemos 2011-2020 metų plètros metmenų patvirtinimo“ yra pažymèta, kad vadovaujantis teisumo principu formuojama ir igyvendinama Lietuvos valstybès sveikatos sistemos politika - „kiekvienas žmogus turi teisę siekti aukščiausio savo sveikatos lygio, tačiau to siekdamas negali riboti tokios pačios kitų žmonių teisès“93.

3. „Teisumo principo sveikatos santykiuose igyvendinimas“ yra pirmasis VLK sveikatos draudimo plètojimo uždavinys, kuris apibūdinamas kaip „sveikatos santykių teisumo principas igyvendinamas susiejant asmeniui skiriamas lěšas su veiksniais, darančiais ịtaką jo sveikatos būklei (amžius, lytis, išsilavinimas, turtinė padètis, šeimyninè padètis ir kt.). ${ }^{\text {"994 }}$

4. Sveikatos apsaugos ministerijos $2009 \mathrm{~m}$. strateginio veiklos plano III tikslas buvo „tobulinti sveikatos sistemos valdymą, sveikatos santykius grịsti teisumo ir solidarumo principais“. Vadovaujantis šiais principais yra užtikrinamas mokesčių naštos padalijimas visiems visuomenès nariams pagal jų pajamų dydị, nepriklausomai nuo jų socialinio statuso. Taip pat siekiama užtikrinti teisingą lèšu administravimą, tolygų gyventojų sveikatos priežiūros poreikių finansavimą, kokybiškų paslaugų teikimą, sveikatos sistemos efektyvumą, racionalų lěšų naudojimą ir kita ${ }^{95}$.

5. Sveikatos apsaugos ministro $2004 \mathrm{~m}$. rugsèjo $14 \mathrm{~d}$. įsakymu Nr. 174 patvirtintoje „Sveikatos priežiūros kokybės užtikrinimo 2005-2010 m. programoje“ buvo pažymèta, kad sveikatos priežiūros kokybès užtikrinimas ir nuolatinis gerinimas igyvendinamas per teisumo dimensiją, kuri apibrèžiama kaip lygių visiško sveikatos potencialo siekimo galimybių kiekvienam asmeniui sudarymas, paskirstant sveikatos priežiūros išteklius bei panaikinant kliūtis ir skirtumus, kuriuos lemia neteisingai traktuojami veiksniai ${ }^{96}$.

92 Lietuvos Respublikos Seimo 1998 m. liepos 2 d. nutarimas Nr. VIII-833 „Dèl Lietuvos sveikatos programos patvirtinimo“. Valstybès žinios. 1998, Nr. 64-1842.

93 Lietuvos Respublikos Seimo 2011 m. birželio 7 d. nutarimas Nr. XI-1430 „Dèl Lietuvos sveikatos sistemos 2011-2020 metų plètros metmenų patvirtinimo“. Valstybès žinios. 2011-06-16, Nr. 73-3498.

94 Valstybine ligonių kasa prie Sveikatos apsaugos ministerijos. Sveikatos draudimo plètojimas, programos aprašymas [interaktyvus]. [žiūrèta 2012-10-06]. <http://www.vlk.lt/vlk/files/str/2008_1b. doc $>$.

95 Lietuvos Respublikos sveikatos apsaugos ministerija, 2011 [žiūrèta 2012-02-18]. <http://www.sam.lt/ go.php/Misija>.

96 Lietuvos Respublikos sveikatos apsaugos ministro $2004 \mathrm{~m}$. rugsèjo 14 d. įsakymas Nr. V-642 „Dèl sveikatos priežiūros kokybès užtikrinimo 2005-2010 m. programos patvirtinimo“. Valstybès žinios. 2004, Nr. 144-5268. 
Sveikatos priežiūros teisumas yra apibūdintas šiuose Lietuvos teisès aktuose:

1. Lietuvos Respublikos sveikatos sistemos įstatymo 2 straipsnio 17 dalyje sveikatos priežiūros teisumas yra apibūdintas kaip „valstybès pripažįstamos sveikatos priežiūros sąlygos lygiomis galimybėmis siekti sveikatos ir kiek įmanoma sumažinant skirtumus tarp jos siekiančių asmenų “97.

2. Lietuvos Respublikos sveikatos sistemos įstatymo 6 straipsnyje yra apibrèžti Lietuvos nacionalinès sveikatos sistemos sudarymo pagrindai, tarp jų yra socialinio teisumo sveikatinimo veikloje užtikrinimas ${ }^{98}$.

Lietuvos teisès aktuose sveikatos santykių teisumas sveikatos priežiūroje yra apibūdinamas sąvoka „sveikatos priežiūros teisumas“. Ši sąvoka yra susijusi su lygybès kontekstu, kai kiekvienam, siekiančiam sveikatos, yra užtikrinama sveikatos priežiūra. Be to, siekiama ìveikti skirtumus tarp siekiančiųjų sveikatos.

Apibendrinant galima teigti, kad Lietuvos teisès aktuose teisumo principas siekiant sveikatos yra apibūdinamas sąvoka „sveikatos santykių teisumas“. Ši sąvoka yra susijusi su teisès kontekstu - kiekvienas žmogus turi teisę siekti sveikatos, bei lygybès kontekstu - siekti sveikatos lygiomis galimybėmis. Būtina paminèti, kad nẻ viename Lietuvos teisiniame dokumente nèra apibūdinta sąvoka „teisumas finansuojant sveikatos priežiūrą“.

Atsižvelgiant ị Lietuvos teisès aktuose ịtvirtintas anksčiau aptartas sąvokas, galima teigti, kad teisine prasme teisumo principo reglamentavimui finansuojant sveikatos priežiūrą skiriama nepakankamai dèmesio.

\section{Teisumo principo užtikrinimas finansuojant sveikatos priežiūrą Lietuvoje}

Jolanta Žemgulienė ir Vilius Grabauskas nacionalinę sveikatos priežiūros finansavimo sistemą ịvardina kaip instrumentą, łgyvendinant teisingą sveikatos finansavimą Lietuvoje ${ }^{99}$.

Galima skirti du svarbius Lietuvos sveikatos sistemos finansavimo etapus, kurie atitinka teisumo principo igyvendinimo kriterijus:

Gyventojų inašai finansuojant sveikatos priežiūra turi atitikti jų finansines galimybes. Mokslininkai sutaria, kad siekiant teisumo finansuojant sveikatos priežiūrą, gyventojų ịnašai turi atitikti žmonių finansines galimybes (mokumą).

Lietuvos Respublikos Konstitucijos 53 straipsnis skelbia: „Valstybė rūpinasi žmonių sveikata ir laiduoja medicinos pagalbą bei paslaugas žmogui susirgus. İstatymas nustato piliečiams nemokamos medicinos pagalbos valstybinèse gydymo ịstaigose teikimo tvarką. "100

1996 m. Lietuvoje prièmus Sveikatos draudimo ịstatymą, pradètas mišrus sveikatos apsaugos finansavimas: privalomojo sveikatos draudimo (PSD) mokesčiais, tiesioginėmis gyventojų i̇mokomis ir išlaidomis bei valstybès ir savivaldybių biudžetų asignavimais. Nuo 1997 m. pagrindiniu sveikatos apsaugos finansavimo šaltiniu tapo Privalomasis sveikatos

97 Lietuvos Respublikos sveikatos sistemos įstatymas $1994 \mathrm{~m}$. liepos 19 d. Nr. I-552. Valstybès žinios. 1994, Nr. 63-1231.

98 Ibid.

99 Žemgulienè, J.; Grabauskas, V. Teisumo principais grindžiamas sveikatos priežiūros finansavimas. Nacionalinès sveikatos tarybos metinis pranešimas 2001. Lietuvos gyventoju bendrosios ir psichikos sveikatos büklès bei sveikatos sistemos organizavimo problemos. Vilnius: „Baltijos kopija“, 2002, p. 83.

100 Lietuvos Respublikos Konstitucija, priimta Lietuvos Respublikos piliečių 1992 m. spalio 25 d. referendume, supra note 4. 
draudimo fondas (PSDF) ${ }^{101}$, o PSD įmokos tapo pagrindiniu sveikatos biudžetą formuojančiu šaltiniu ${ }^{102}$. „Privalomąji sveikatos draudimą vykdo Privalomojo sveikatos draudimo taryba, Valstybinè ligonių kasa prie Sveikatos apsaugos ministerijos ir teritorinès ligonių kasos. " ${ }^{103}$

2009 m. yra ịvestos 9 proc. PSD įmokos, kurios skaičiuojamos nuo asmens uždirbamų pajamų. „PSD įmokos tapo pagrindiniu sveikatos biudžetą formuojančiu šaltiniu. "104 Tai reiškia, kad įmokos ị PSDF biudžetą yra renkamos užtikrinant teisumo principą - įmokos mokamos pagal žmonių mokumą, t. y. jų uždirbamas pajamas. Valstybès biudžetas sumoka įmokas už ekonomiškai silpnas gyventojų grupes, kurios yra reglamentuotos Lietuvos Respublikos sveikatos draudimo ịstatymo 6 straipsnio 4 dalyje ${ }^{105}$.

Sveikatos draudimo istatyme ${ }^{106}$ yra nustatyta, kad visi asmenys, kurie yra apsidraudę privalomuoju sveikatos draudimu ir sumokeję PSD įmokas, turi vienodas teises ị sveikatos priežiūros paslaugas - jos yra teikiamos pagal poreikị, nepriklausomai nuo sumokètų i̇mokų dydžio per mokesčius finansuojant PSDF biudžetą. Šios ịstatymo nuostatos parodo, kad Lietuvoje yra iggvendinamas privalomojo sveikatos draudimo modelis, grindžiamas ne tik teisumo, tačiau ir solidarumo principu - šie principai vienas kitą papildo.

Teisumu grindžiamas sveikatos priežiüros finansavimo paskirstymas. Išteklių skirstymas reikalauja ypatingai stiprios ir nuoseklios valstybès politikos. Politikai turi stengtis ne tik efektyviai panaudoti valstybès lěšas, tačiau skirstant jas vadovautis ir teisumo principu.

Vienas iš svarbiausių veiksnių sveikatos sistemoje yra finansavimo įnašų teisingas paskirstymas ${ }^{107}$. Tai reiškia, kad skirstant PSD įmokas, kuriomis finansuojama sveikatos priežiūra, turi būti vadovaujamasi teisumo principu.

Finansavimo įnašų paskirstymą aptaria ir Danguole Jankauskienẻ bei bendraautoriai: „finansavimo mechanizmas, atitinkantis teisingumo kriterijus, yra susijęs su lěšų perskirstymu (turtingesnių gyventojų įnašais, kurie pagal teisingo finansavimo įnašo principą yra didesni, iš dalies yra finansuojama vargingesnių gyventojų sveikatos priežiūra).“108 Tai patvirtina J. Žemguliene ir V. Grabauskas teigdami, kad „draudimo priemonemis sveikatos priežiūros finansavimas paskirstomas tarp draudimo fondo narių, t. y. sveikųjų įnašais yra finansuojama pagalba sergantiesiems. Socialinès sveikatos draudimo sistemos sudaro prielaidas perskirstyti sveikatos priežiūros finansavimą tarp gaunančiųjų didesnes ir mažesnes pajamas ${ }^{109 “}$.

Lėšų perskirstymas finansuojant sveikatos priežiūrą užtikrina vargingesnių gyventojų galimybes siekti geros sveikatos bei naudotis sveikatos priežiūros paslaugomis ${ }^{110}$.

Socialinio draudimo principas Lietuvoje buvo pasirinktas kaip priemonė, užtikrinanti ne tik sveikatos priežiūros kokybę ir sveikatos priežiūros paslaugų teikimo efektyvumą, ta-

101 Žemgulienè, J.; Grabauskas, V., supra note 99, p. 70.

102 Gudžinskas, L. Lietuvos ir Estijos sveikatos apsaugos raida: panašios sąlygos, skirtingi rezultatai. Politologija. 2012, 3(67): 74.

103 Valstybinè ligonių kasa prie Sveikatos apsaugos ministerijos [žiūrèta 2013-03-09]. <http://www.vlk.lt/ $\mathrm{vlk} / \mathrm{lt} /$ ?page=info\&id=121>.

104 Gudžinskas, L., op cit., p. 74.

105 Lietuvos Respublikos sveikatos draudimo įstatymas 1996 m. gegužès 21 d. Nr. I-1343. Valstybès žinios. 1996, Nr. 55-1287.

106 Ibid.

107 Napierala, C. Finance equity comparison of health system. 2008, p. 35-36.

108 Jankauskiené, D., et al. Išlaidų sveikatos priežiūrai kitimo tendencijos Lietuvoje 1994-1999 m. Medicina. 2002, 38 (9): 933.

109 Žemguliene, J.; Grabauskas, V., supra note 99, p. 83.

110 Jankauskienè, D., et al., supra note 108, p. 933. 
čiau ir sveikatos santykių teisumą ${ }^{111}$. Algis Sasnauskas atkreipia demesị i tai, kad privalomojo sveikatos draudimo sistema atitinka ES šalių filosofiją ir igyvendina socialinès valstybės principus - teisumą ir solidarumą ${ }^{12}$.

VLK strateginiame tiksle yra pabrèžta, kad yra svarbu užtikrinti apdraustųjų sveikatos priežiūrą ne tik kompensuojant išlaidas, tačiau skaidriai ir efektyviai naudojant PSDF biudžeto lěšas. Terminas „skaidrumas“ yra sveikatos santykių, užtikrinant teisumo principą, dalis. Šis VLK strateginis tikslas igyvendinamas vadovaujantis pagrindiniais socialinio sveikatos draudimo modelio principais: tolygiai finansuojant gyventojų sveikatos priežiūros poreikius, teisingai administruojant lèšas bei didelị dėmesị skiriant didesnès apimties ir geresnèms paslaugoms ${ }^{113}$.

Lietuvos sveikatos programoje yra išskirtas Lietuvos sveikatos priežiūros finansavimo sveikatos draudimo igyvendinimas, kurio tolesnị išteklių pasiskirstymą lemia du principai ${ }^{114}$ :

Tolygus gyventoju finansavimas. „Tokiu būdu galètų būti sprendžiamos problemos, susijusios su gyventojų sveikatos būklès gerẻjimo užtikrinimu. Būtina didesnę lèšų dalị nukreipti ị gyventojus kaip ì potencialius pacientus. Visuomenès sveikatos priežiūros, PSP plètra kartu su sveikatos priežiūros integravimu ị socialinių paslaugų plètros programą - tai prielaida, kad potencialūs pacientai netaps realiais pacientais. Toks problemos sprendimas užtikrina santykinį išlaidų minimizavimą, mažèjant pacientų, gydomų stacionaruose, srautui. Tolygus gyventojų finansavimas turi būti užtikrintas privalomojo sveikatos draudimo lěšas skirstant teritorinèms ligonių kasoms pagal jų aptarnaujamą gyventojų skaičių."

Sveikatos priežiūros paslaugu finansavimas atsižvelgiant ị naudingumą. „Prioritetiškai turi būti finansuojamos sveikatos priežiūros paslaugos ir atitinkamos medicinos technologijos, kurios užtikrina kuo didesnę naudą pacientams. Priimant sprendimus dèl prioritetų, vertètų analizuoti, kiek papildomų paciento kokybiško gyvenimo metų užtikrina alternatyvios sveikatos priežiūros technologijos.

Strateginiai spendimai sveikatos finansavimo srityje priimami ịvairių socialinių, ekonominių, teritorinių gyventojų gupių atžvilgiu, todèl sveikatos priežiūros finansavimo netolygumo problemos aktualios tarp gyventojų grupių pagal socialinius, demografinius, ekonominius požymius." ${ }^{115}$

Lietuvos sveikatos programoje tolygus gyventojų finansavimas apibūdinamas kaip privalomojo sveikatos draudimo lěšų skirstymas TLK pagal jų aptarnaujamą gyventojų skaičių ${ }^{116}$. VLK pažymi, kad teisumo principas sveikatos santykiuose igyvendinamas susiejant asmeniui skiriamas lèšas su veiksniais, darančiais įtaką jo sveikatai (amžius, lytis, išsilavinimas, turtinė padètis, šeiminė padètis ir kt.). VLK aptartą principą igyvendina keliais lygmenimis ${ }^{117}$ :

$111 \quad$ Ibid., p. 933.

112 Lietuvos sveikatos sektorius amžiu sandūroje. Vilnius: UAB Sveikatos ekonomikos centras, 2010, p. 391-392.

113 Valstybinè ligonių kasa prie Sveikatos apsaugos ministerijos. 2010 metų veiklos ataskaita [interaktyvus]. Vilnius, 2011, p. 5 [žiūrèta 2012-01-28]. <http://www.vlk.lt/vlk/files/2011/veikla/2010_VLK_veiklos_ ataskaita.pdf $>$.

114 Lietuvos Respublikos Seimo 1998 m. liepos 2 d. nutarimas Nr. VIII-833 „Dèl Lietuvos sveikatos programos patvirtinimo“, supra note 92.

115 Žemgulienè, J.; Grabauskas, V., supra note 99, p. 84.

116 Lietuvos Respublikos Seimo 1998 m. liepos 2 d. nutarimas Nr. VIII-833 „Dèl Lietuvos sveikatos programos patvirtinimo", supra note 92.

117 Valstybinè ligonių kasa prie Sveikatos apsaugos ministerijos. Sveikatos draudimo sistemos vystymas, 2004 [interaktyvus]. [žiūrèta 2012-01-12]. <http://www.vlk.lt/vlk/za_kt/files/vlk_str_pl_ap.doc>. 
Administracinio teritorinio vieneto lygmeniu. „PSDF biudžeto lèšos skirstomos pagal vieningus demografinius bei socialinius ekonominius statistinius rodiklius. "118

„Siekiant tolygiai finansuoti šalies gyventojų sveikatos priežiūrą, atsižvelgiama ne tik i atskirų regionų gyventojų skaičių, tačiau yra ịvertintos stacionarinių bei ambulatorinių paslaugų, suteiktų skirtingo amžiaus (14 amžiaus grupių) bei lyties gyventojams, išlaidos. "VLK duomenimis, mažiausiai sveikatos priežiūros išlaidų tenka 10-40 metų amžiaus gyventojams: minètos išlaidos beveik du kartus mažesnès nei nuo 1-9 metų amžiaus ir net tris kartus mažesnès nei 70-80 metų amžiaus gyventojų. Siejant gyventojų amžių su sveikatos priežiūros paslaugų poreikiu, daugiau lěšų turi būti skiriama tiems regionams, kuriuose daugiau senyvo amžiaus gyventojų ${ }^{119}$.

Paslaugu teikéjo lygmeniu. Šiuo lygmeniu teisumo principas užtikrinamas skirstant sveikatos priežiūros paslaugas, kurios yra apmokamos iš PSDF biudžeto. Teikiamos paslaugos yra skirstomas atsižvelgiant ị gyventojų poreikius, tam tikrus veiksnius, susijusius su sveikatos būkle (amžius, lytis, išsilavinimas, šeiminè padètis, turtinè padètis ir kt.) bei užtikrinant paslaugų teikimo reikalingos infrastruktūros funkcionavimą ${ }^{120}$.

„Paslaugų teikejo lygmeniu teisumo principas igyvendinamas diferencijuojant paslaugų, apmokamų iš PSDF biudžeto, kiekị pagal gyventojų poreikius ir atsižvelgiant ị šių veiksnių ịtaką tam tikrų ligų ar jų formų paplitimui bei užtikrinant paslaugų teikimo infrastruktūros funkcionavimą."

Siekiant teisumo finansuojant sveikatos sistemą ir naudojantis sveikatos priežiūros paslaugomis, sveikatos apsaugos sistemos gali pasitelkti įvairias politines ir ekonomines priemones. Skirstant išteklius pagal regionus kai kurios šalys naudoja formules, pagrịstas demografiniais duomenimis ${ }^{122}$.

Lietuvoje yra naudojamos PSDF lèšų paskirstymo formulès, kurios parengtos padedant švedų konsultantams, o skirstant lèšas atsižvelgiama ị gyventojų skaičių, amžių (14 amžiaus grupių), lytị, gyvenamąją vietą (miestas, kaimas), praejusio laikotarpio faktinị paslaugų vartojimą. Pirmosios PSDF lèšų paskirstymo TLK formulès buvo patvirtintos 2004 m., o pradètos naudoti 2005 m., o visiškai ịgyvendintos per trejus metus ${ }^{123}$.

Apibendrinant galima teigti, kad teisumo principas finansuojant Lietuvos sveikatos priežiūrą iggyvendinamas, kadangi įmokos mokamos pagal mokumą (pajamas) bei už tuos, kurie neturi pajamų, mokama iš valstybės biudžeto, o lešos paskirstomos pagal formulę, kurios tobulinimas yra ateities politikos uždavinys.

118 Ibid.

119 Ibid.

120 Ibid.

121 Kumpienè, J., et al. Sveikatinimo veiklos finansavimas ir ekonominis reguliavimas. Nacionalinès sveikatos tarybos metinis pranešimas. Lietuvos sveikatos programos igyvendinimas: pasiekimai ir problemos. Vilnius: „B altijos kopija“, 2005, p. 92.

122 McPake, B., et al. Health economics: an international perspective. London: Routledge, 2002.

123 Sasnauskas A. Privalomasis sveikatos draudimas Lietuvoje: įveikti iššūkiai ir laukiantys darbai. Ligoniu kasu trečiosios metinès konferencijos „Ligoniu kasos Lietuvoje. Kas nuveikta per 20 metu??" medžiaga [interaktyvus]. Vilnius, $2012 \mathrm{~m}$. sausio 26 d. [žiūrèta 2012-02-10]. <http://www.vlk.lt/resources/ files/2012/veikla/IIIkonf_AlgisSasnauskasED.pdf>. 


\section{Išvados}

1. Teisumo principo sampratos interpretacijų yra įvairių, jos priklauso nuo mokslo srities atstovo, kuris ją interpretuoja. Lietuvos Respublikos teisès aktuose sveikatos santykių teisumo sąvoka yra apibūdinta, tačiau sveikatos priežiūros teisumo sąvoka nèra pakankamai ir detaliai reglamentuota.

2. Mokslininkai sutaria, kad teisumas finansuojant sveikatos priežiūrą yra užtikrinamas, kai finansuojant sveikatos priežiūrą yra atsižvelgiama ị žmonių gebejjimą mokèti. Sveikatos sistemos visuomeninio finansavimo teisumas glaudžiai siejasi su solidarumo principu, kadangi mokumas yra susijęs su žmonių finansinėmis galimybėmis, kai turtingesni žmonès moka didesnę savo pajamų dalį už sveikatos priežiūrą, o neturtingesni - mažesnę.

3. Lietuvos sveikatos priežiūros teisinio reguliavimo srityje teisumo principo užtikrinimas finansuojant Lietuvos sveikatos sistemą nèra visiškai apibrèžtas, tačiau yra reglamentuotos priemonès, kuriomis siekiama teisumo renkant įmokas į PSDF biudžetą: įmokos mokamos pagal žmonių mokumą, jų uždirbamas pajamas, o už ekonomiškai silpnas gyventojų grupes - i̇mokos mokamos iš valstybès biudžeto, lěšos paskirstomos teritorinėms ligonių kasoms pagal formulę, kurios tobulinimas yra ateities uždavinys.

\section{Rekomendacijos}

Tikslinga Lietuvos Respublikos sveikatos sistemos ịstatyme reglamentuoti sveikatos priežiūros teisumo sąvoką (per sveikatos priežiūros prieinamumą, finansavimą, išlaidas, kokybę, naudojimą) bei papildyti ir reglamentuoti sveikatos sistemos finansavimo principus, sveikatos priežiūros finansavimo ir sveikatos priežiūros visuomeninio finansavimo teisumo sąvokas bei priemones jiems igyvendinti.

Tikslinga Lietuvos Respublikos sveikatos draudimo ịstatymo III dali papildyti ir reglamentuoti Privalomojo sveikatos draudimo fondo biudžeto pajamų sudarymą, vadovaujantis teisumo principu.

Tikslinga svarstyti galimybę pakeisti Lietuvos Respublikos teisės aktus, numatant paciento atsakomybę už savo sveikatos žalojimą (rizikingą elgseną) - žalingus ịpročius, gydytojo nurodymų nevykdymą, profilaktinius nesilankymus pas gydytojus.

Rekomenduojama organizuoti ir vykdyti mokymus teisumo principo igyvendinimo sveikatos priežiūros sistemoje temomis, skirtus Lietuvos sveikatos politikos formuotojams ir igyvendintojams.

\section{Literatūra}

1. Acuca, D. L., et al. Access to and Financing of Health Care: Ways to Measure Inequities and Mechanisms to Reduce Them. Equity and Health. Washington: Pan American Health Organization, 2001, 8, p. 115-127.

2. Bambas, A.; Casas, J. Assessing Equity in Health: Conceptual Criteria. Equity and Health. Washington: Pan American Health Organization, 2001, 8, p. 12-21.

3. Balancing Equity and Efficiency [interaktyvus]. [žiūrèta 2012-03-09]. <http:// www.healthknowledge.org.uk/public-health-textbook/medical-sociology-policyeconomics/4c-equality-equity-policy/balancing-equity-efficiency $>$.

4. Braveman, P.; Gruskin, S. Poverty, equity, human rights and health. Bulletin of the World Health Organization. 2003, 81(7): 539-545. 
5. Braveman, P.; Gruskin, S. Defining equity in health. Journal of Epidemiology \& Community Health. 2003, 57.

6. Commission on Social Determinants of Health. Towards a Conceptual Framework for Analysis and Action on the Social Determinants of Health. Discussion paper for the Commission on Social Determinants of Health. 2005.

7. Dahlgren, G.; Whitehead, M. Policines and strategies to promote equity in health. WHO, Copenhagen, 1992, p. 1-60.

8. Dahlgren, G.; Whitehead, M. Concepts and principles for tackling social inequities in health (Levelling up Part 1). WHO European Office for Investment for Health and Development, 2006.

9. Drouin, D. Methods of financing health care: A rational use of financing mechanisms to achieve universal coverage. Technical Commission on Statistical, Actuarial and Financial Studies. Geneva: International Social Security Association, 2007.

10. Europos Komisija. Naujas tyrimas rodo, kad vis daugiau žmoniu skursta, 2010 [interaktyvus]. [žiūrèta 2012-02-18]. <http://europa.eu/rapid/pressReleasesAction.do?re ference $=\mathrm{IP} / 10 / 773 \&$ format $=$ HTML\&aged $=0$ \&language $=$ LT\&guiLanguage $=e n>$.

11. Evans, T., et al. Challenging Inequalities in Health: from ethics to action. Oxford: Oxford University Press, 2001, p. 68-75.

12. Gabr, M. Health Ethics, Equity and Human Dignity [interaktyvus]. [žiūrèta 2013-02-09]. $<$ http://www.humiliationstudies.org/>.

13. George, A. O. Alleyne. Equity and health. Equity and Health. Washington: Pan American Health Organization, 2001, 8: 3-12.

14. Grabauskas, V. J. Lietuvos sveikatos priežiūra Europos Sajungos ir pasaulio kontekste. Lietuvos sveikatos sektorius amžiu sandūroje. Vilnius: UAB Sveikatos ekonomikos centras, 2010, p. 84-97.

15. Graeve, D. D.; Xu, K. Health Finance, Equity in Health System Policy, Finance and Organization, edited Carrin G. Geneva, Switzerland, 2008, p. 195-203.

16. Gruen, R.; Howarth, A. Managing Health Services Finance. 2005.

17. Gudžinskas, L. Lietuvos ir Estijos sveikatos apsaugos raida: panašios sąlygos, skirtingi rezultatai. Politologija. 2012, 3(67): 62-94.

18. Gottschalk, P., et al. Health care financing in U.S., U.K. and Netherlands: distributional consequences. Changes Revenue Structures. Detroit: Wayne State University Press, p. 351-373.

19. Hurst, J. W. Reforming health care in seven European nations. Health Affairs. 1991, 10(3): $7-21$.

20. Hoare, G.; Mills, A. Paying for the Health Sector: A Review and Annotated Bibliography of the Literature on Developing Countries. London: London School of Hygiene and Tropicla Medicine, Evaluation and Planning Center for Health Care, 1986, 12.

21. Hsiao, W. C.; Liu, Y. Health Care Financing: Assessing Its Relationships to Health Equity, Equitable Health Care System. Challenging Inequities in Health, from Ethics to Action. New York, Oxford University Press, 2001.

22. Jakutytè, S. Teisingumo teorijos taikymas sveikatos priežiūroje: galimybès ir ribos [interaktyvus]. 2001, p. 4 [žiūrèta 2012-02-04]. <www.ebiblioteka.lt/resursai/LMA/ Filosofija/F-03.pdf $>$.

23. Kawachi, I., et al. A glossary for health inequalities. Journal of epidemiology and Community Health [interaktyvus]. 2002, 56 [žiūrèta 2013-03-12]. <http://jech.bmj.com/ content/56/9/647.full>. 
24. Kumpienè, J., et al. Lietuvos nacionalinė sveikatos sąskaita. Nacionalinès sveikatos tarybos metinis pranešimas 2004. Lietuvos sveikatos programos igyvendinimas: pasiekimai ir problemos. Vilnius: BI „Baltijos kopija“, 2005, p. 85-91.

25. Kutzin, J. Health finansing policy: a guide of decision-makers. Health Financing Policy Paper, Division of Country Health Systems. WHO Regional Office for Europe Copenhagen, Denmark, 2008.

26. Klein, R.; Huang, D. Defining and measuring disparities, inequities, and inequalities in the Healthy People initiative. National Center for Health Statistics Centers for Disease Control and Prevention [interaktyvus]. [žiūrèta 2012-01-05]. <http://www.cdc.gov/nchs/ ppt/nchs2010/41_Klein.pdf $>$.

27. Leenan, H. Equality and equity in health care. Paper presented at the WHO/Nuffield Centre for Health Service Studies meeting. Leeds, 1985.

28. Lundberg, M.; Wang, L. Health sector reforms. Analyzing the Distributional Impact of Reforms. The World Bank, Washington, 2006, 2, p. 43-110.

29. Lietuvos sveikatos reforma: dabartis ir ateitis. Nacionalinės sveikatos tarybos posėžio rezoliucija. Sveikatos drauda. 2000, 12 (43): 3-4.

30. Lietuvos sveikatos sektorius amžiu sandūroje. Vilnius: UAB Sveikatos ekonomikos centras, 2010.

31. Lietuvių kalbos žodynas [interaktyvus]. [žiūrèta 2012-07-13]. <http://www.lkz.lt>.

32. Lietuvos Respublikos sveikatos sistemos įstatymas Valstybès žinios. 1994, Nr. 63-1231.

33. Lietuvos Respublikos Seimo 1998 m. liepos 2 d. nutarimas Nr. VIII-833 „Dèl Lietuvos sveikatos programos patvirtinimo“. Valstybės žinios. 1998, Nr. 64-1842.

34. Lietuvos Respublikos Seimo 2011 m. birželio 7 d. nutarimas Nr. XI-1430 „Dèl Lietuvos sveikatos sistemos 2011-2020 metų plètros metmenų patvirtinimo“. Valstybès žinios. 2011, Nr. 73-3498.

35. Lietuvos Respublikos sveikatos draudimo įstatymas. Valstybės žinios. 1996, Nr. 55-1287.

36. Lietuvos Respublikos sveikatos apsaugos ministro $2004 \mathrm{~m}$. rugsėjo $14 \mathrm{~d}$. ìsakymas Nr. V-642 „Dèl sveikatos priežiūros kokybès užtikrinimo 2005-2010 m. programos patvirtinimo“. Valstybès žinios. 2004, Nr. 144-5268.

37. Lietuvos Respublikos Konstitucija, priimta Lietuvos Respublikos piliečių 1992 m. spalio 25 d. referendume. Valstybès žinios. 1992, Nr. 33-1014.

38. Lietuvos Respublikos sveikatos apsaugos ministerija [žiūrèta 2012-02-18]. <http://www. sam.lt/go.php/Misija>.

39. Lietuvos sveikatos sveikatos programa 2020 [interaktyvus]. [žiūrèta 2012-02-18]. <http:// www.sveikatosprojektai.org/node/41>.

40. 1996 m. birželio $18 \mathrm{~d}$. Liublianos chartija dèl sveikatos apsaugos reformų Europoje [interaktyvus]. [žiūrèta 2012-02-23]. <http://sec.lt/pages/spr/Alf_mok/Priedai/Chatija. html>.

41. McPake, B., et al. Health economics: an international perspective. London: Routledge, 2002.

42. Morris, S., et al. Inequity and inequality in the use of health care in England: an empirical investigation. Social Science and Medicine. 2005.

43. Murray, C. J. L.; Frenk, J. A framework for assessing the performance of health systems. Bulletin of the World Health Organization. 2000, 78 (6): 717-731.

44. Murray, C. J. L., et al. Defining and measuring fairness in financial contribution to the health system. World Health Organization, GPE Discussion Paper Series: No. 24.

45. Musgrove, P. Health Economics in Development. The World Bank: Washington, 2004. 
46. Napierala, C. Finance Equity Comparison of Health System. 2008.

47. Pasaulio sveikatos organizacijos biuras Lietuvoje. Kaip panaikinti atotrūkị per vienos kartos gyvenamaji laikotarpi siekiant sveikatos santykiu teisumo per socialinius sveikatos veiksnius. Kaunas: UAB Spaudos brokeris, 2009.

48. Picavet, H. S. J. Perspectives on Health Inequity. Edited by Harris E., Sainsbury S., Nutbeam D. Sydney: The Australian Centre for Health Promotion, 1999.

49. Poteete, A. R. Is Decentralization a reliable mans of increasing equity? New Orleans, Los Angeles, 2004 [interaktyvus]. [žiūrèta 2011-12-12]. <http://dlc.dlib.indiana.edu/dlc/ bitstream/handle/10535/2246/Poteete_Decentralization_and_Equity.pdf >.

50. Sasnauskas, A. Privalomasis sveikatos draudimas Lietuvoje: įveikti iššūkiai ir laukiantys darbai. Ligoniu kasu trečiosios metinès konferencijos „Ligoniu kasos Lietuvoje. Kas nuveikta per 20 metų? medžiaga [interaktyvus]. Vilnius [žiūrèta 2012-01-26]. <http:// www.vlk.lt/resources/files/2012/veikla/IIIkonf_AlgisSasnauskasED.pdf>.

51. Secretary's Advisory Committee on National Health Promotion and Disease Prevention Objectives for 2020. Revised definitions for health disparities and health equity [interaktyvus]. [žiūrèta 2013-01-07]. <http://healthypeople.gov/2020/about/advisory/ FACA6Minutes.aspx?page $=2>$.

52. Shakarishvili, G. Poverty and Equity in Healthcare Finance: Analyzing Post-Soviet Healthcare Reform. Hungary, 2006.

53. Social justice and equity in health: report on a WHO meeting (Leeds, United Kingdom, 1985). Copenhagen, Regional Office for Europe, 1986 (ICP/HSR804/m02).

54. The World Bank. Equity and Development. World Development Report 2006. New York: Oxford University Press, 2006, p. 2-22.

55. Thomson, S., et al. Financing health care in the Europian unijon: challenges and policy responses. Copenhagen: Printed in the European Union, 2009.

56. van Doorslaer, E.; O'Donnell, O. Measurement and Explanation of Inequality in Health and Health Care in Low-Income Settings. UNU-WIDER World Institute for Development Economics Research, Discussion Paper, 2008.

57. Valstybinè ligonių kasa prie Sveikatos apsaugos ministerijos. Sveikatos draudimo plètojimas, programos aprašymas [interaktyvus]. [žiūrèta 2012-10-06]. <http://www.vlk. lt/vlk/files/str/2008_1b.doc >.

58. Valstybinè ligonių kasa prie Sveikatos apsaugos ministerijos. 2010 metų veiklos ataskaita [interaktyvus]. Vilnius, 2011 [žiūrèta 2012-01-28]. < http://www.vlk.lt/vlk/files/2011/ veikla/2010_VLK_veiklos_ataskaita.pdf $>$.

59. Valstybinė ligonių kasa prie Sveikatos apsaugos ministerijos. Sveikatos draudimo sistemos vystymas, 2004 [interaktyvus]. [žiūrèta 2012-01-12]. <www.vlk.lt/vlk/za_kt/ files/vlk_str_pl_ap.doc $>$.

60. Zschock, D. K. Health sector disparities in Peru. Bulletin of the Pan American Health Organization. 1989, 23(3).

61. Žemgulienè, J.; Grabauskas, V. Teisumo principais grindžiamas sveikatos priežiūros finansavimas. Nacionalinès sveikatos tarybos metinis pranešimas 2001. Lietuvos gyventoju bendrosios ir psichikos sveikatos bükles bei sveikatos sistemos organizavimo problemos. Vilnius: „Baltijos kopija“, 2002, p. 82-86.

62. Wagstaff, A. J.; van Doorslaer, E. Equity in the finance of health care: Some international comparisons. Journal of Health Economics. North Holland, 1992, p. 361-387.

63. Wagstaff, A. J., et al. Equity in the finance of health care: some further international comparisons. Journal of Health Economics. 1999, p. 263-290. 
64. Wagstaff, A. J., et al. On the measurement of horizontal inequity in the delivery of health care. Journal of Health Economics. North Holland. 1991, p. 169-205.

65. Wagstaff, A. J., et al. Equity in the Finance and Delivery of Health Care: Some Tentative Cross-Country Comparisons. Oxford Review of Economic Policy. Oxford university press, 1989, 5(1): 89-112.

66. Wagstaff, A. J.; van Doorslaer, E. Equity in Health Care Financing and Delivery. North Holland Handbook of Health Economics, edited Culyer A. J., Newhouse J. P. 1998.

67. Whitehead, M. The concepts and principles of equity and health. World Health Organization Regional Office for Europe Copenhagen, 1990.

68. Whitehead, M. The concepts and principles of equity and health. International Journal of Health Services. 1992.

69. World Health Organization. Health systems: improving perfomance. The World Health Report. 2000.

70. World Health Organization. The Solid Facts: Social Determinants of Health / 7th ed. Copenhagen: World Health Organization, 2003.

71. World Health Organization. The world health report [interaktyvus]. [žiūrèta 2013-02-27] <http://www.who.int/whr/2008/overview/en/index.html>.

72. World Health Organization. Social determinants of health [žiūrèta 2013-03-12]. <http:// www.who.int/social_determinants/thecommission/finalreport/key_concepts/en/index. html>.

\title{
Equity as the Main Principle of Public Financing of Health System
}

\author{
Dainora Bielskytè \\ Klaipeda City Public Health Bureau, Lithuania \\ Danguolè Jankauskienè \\ Mykolas Romeris University, Lithuania
}

\section{Summary}

The article investigates the necessity of the equity principle from the theoretical point of view. It provides the systemic analysis of the equity principle, its role in health care and health care financing. Besides, it analyses the Lithuanian legal acts, which regulate the notion of the equity principle, and the instruments, which guarantee its fulfillment.

Results and recommendations. There are different types of equity principle notion interpretations, which depend on the representative of the academic field of the scientist, who presents findings. The systemic analysis showed that the best interpretation of equity would be equal opportunities of seeking health and receiving equal health results through transparent distribution of resources not dependent on social economic status of population. In the Legal Acts of the Republic of Lithuania, the health care notion of equity is explained in a very narrow meaning. There are some suggestions to regulate it through accessibility, financing, expenses, quality and consuming of health care. The guarantee of the equity principle while financing Lithuanian health system is not well defined in the Legal Acts of the Republic of Lithuania, only instruments are regulated. Public financing in Lithuania is guaranteed through collecting health insurance taxes based on personal income. Also, distribution of financing is assured by the distribution formula, which could be improved in future. It is suggested to regulate the notions more in the financing of health care equity and social financing of health care. 
Keywords: health system financing, public financing, equity principle in the health system financing, equity principle.

Dainora Bielskytė, Klaipėdos miesto visuomenès sveikatos biuro visuomenès sveikatos specialistè.

Danguolè Jankauskienė, Mykolo Romerio universiteto Politikos ir vadybos fakulteto prodekanè, Politikos mokslų instituto profesorè, biomedicinos mokslų daktarè.

Dainora Bielskytè, Public Health Specialist, Klaipeda City Public Health Bureau.

Danguolè Jankauskienè, Doctor of Biomedicine, is Vice-Dean for Studies at the Faculty of Policy and Management, Professor at the Institute of Political Sciences, Mykolas Romeris University. 